University of Nebraska - Lincoln

DigitalCommons@University of Nebraska - Lincoln

2006

\title{
Thermal conditioning of fifth-instar Cydia pomonella (Lepidoptera: Tortricidae) affects HSP70 accumulation and insect mortality
}

X. Yin

Washington State University

S. Wang

Washington State University

J. Tang

Washington State University

J. D. Hansen

USDA-ARS

S. Lurie

Agricultural Research Organization

Follow this and additional works at: https://digitalcommons.unl.edu/entomologyother

Part of the Entomology Commons

Yin, X.; Wang, S.; Tang, J.; Hansen, J. D.; and Lurie, S., "Thermal conditioning of fifth-instar Cydia pomonella (Lepidoptera: Tortricidae) affects HSP70 accumulation and insect mortality" (2006). Entomology Papers from Other Sources. 14.

https://digitalcommons.unl.edu/entomologyother/14

This Article is brought to you for free and open access by the Entomology Collections, Miscellaneous at DigitalCommons@University of Nebraska - Lincoln. It has been accepted for inclusion in Entomology Papers from Other Sources by an authorized administrator of DigitalCommons@University of Nebraska - Lincoln. 


\title{
Thermal conditioning of fifth-instar Cydia pomonella (Lepidoptera: Tortricidae) affects HSP70 accumulation and insect mortality
}

\author{
X. Y I N ${ }^{1,2}, \mathrm{~S} . \mathrm{WA} \mathrm{NG}^{1}, \mathrm{~J} . \mathrm{TANG}^{1}, \mathrm{~J} . \mathrm{D} . \mathrm{HANSEN} \mathrm{N} \mathrm{N}^{3}$ and S. L U R E ${ }^{4}$ \\ ${ }^{1}$ Department of Biological Systems Engineering, Washington State University, Pullman, Washington, U.S.A., ${ }^{2}$ College of \\ Plant Protection, Henan Agricultural University, Zhengzhou, Henan, P. R. China ${ }^{3}$ USDA-ARS Yakima Agricultural \\ Research Laboratory, Wapato, Washington, U.S.A. and ${ }^{4}$ Department of Postharvest Science, Agricultural Research \\ Organization, Volcani Center, Bet Dagan, Israel
}

\begin{abstract}
Levels of HSP70 protein of fifth-instar codling moth [Cydia pomonella (L.) (Lepidoptera: Tortricidae)] are determined after conditioning at $35{ }^{\circ} \mathrm{C}$ for different times and also after recovery at $22{ }^{\circ} \mathrm{C}$. Protein samples from larvae conditioned for different times are separated by sodium dodecyl sulphate-polyacrylamide gel electrophoresis electrophoresis. Sub-lethal thermal conditioning at $35{ }^{\circ} \mathrm{C}$ for $40 \mathrm{~min}, 2,6$ and $18 \mathrm{~h}$ induces new protein bands in the extracts from treated codling moth larvae. Immunodetection with an antibody to a heat-inducible HSP70 indicates a stronger reaction after $35^{\circ} \mathrm{C}$ for 2,6 and $18 \mathrm{~h}$ than after $35{ }^{\circ} \mathrm{C}$ for $40 \mathrm{~min}$ or control and, during the recovery period at $22{ }^{\circ} \mathrm{C}$, the level of heat shock protein decreases. Conditioning of fifth-instar codling moths at $35^{\circ} \mathrm{C}$ also induces thermotolerance in the insects and necessitates longer times at a lethal temperature to ensure mortality. Thermotolerance is correlated with the accumulation of heat inducible HSP70 protein.
\end{abstract}

Key words. Cydia pomonella, fruit pest species, heat shock protein, pest management, preconditioning, thermal resistance.

\section{Introduction}

Codling moth larvae, Cydia pomonella (L.) (Lepidoptera: Tortricidae), are important cosmopolitan quarantine insect pests of fruits and nuts (Barnes, 1991; Wearing et al., 2001; Hansen et al., 2002). Quarantine regulations in Japan and South Korea require all immature life stages of the codling moth to be killed in postharvest treatments of fresh fruits (Ministry of Agriculture et al. 1950; Ministry of Agriculture and Forestry - Republic of Korea, 1982). Currently, methyl bromide fumigations control codling moth larvae, but international agreements for environmental and health reasons may restrict their future use (Hallman \& Mangan, 1997), and thermal postharvest procedures are being developed as alternative treatment. Thus, knowledge of the

Correspondence: Dr Susan Lurie, Department of Postharvest Science, Agricultural Research Organization, Volcani Center, Bet Dagan 50250, Israel. Tel.: ; fax: +972 3 9683622; e-mail: slurie43@ agri.gov.il intrinsic heat tolerance of the codling moth is needed to develop an effective heat treatment and to gain insight into how the heat tolerance is affected by various postharvest conditions.

Enhanced thermotolerance of insect pests after exposure to nonlethal temperatures is correlated with the induction of heat shock proteins (HSP) (Dahlgaard et al., 1998; Neven, 2000). Research into inducible insect HSPs is useful because temperature fluctuations in the field or during the postharvest period can cause a heat shock response, which could subsequently compromise the efficacy of thermal treatments (Hallman \& Mangan, 1997). An increase in heat resistance occurs in the Mediterranean fruit fly, Ceratitis capitata after exposure to sublethal temperatures between 32 and $42{ }^{\circ} \mathrm{C}$ (Jang, 1992; Feder et al., 1996); the Queensland fruit fly, Bactrocera tryoni (Beckett \& Evans, 1997; Waddell et al., 2000); the flesh fly, Sarcophaga crassipalpis (Yocum \& Denlinger, 1992); and the light brown apple moth, Epiphyas postvittana (Beckett \& Evans, 1997; Lester \& Greenwood, 1997). Hallman (1994) show that the third instars of the Caribbean fruit fly, Anastrepha 
suspensa, reared at $30{ }^{\circ} \mathrm{C}$ are significantly more heat tolerant than those reared at $20^{\circ} \mathrm{C}$. Thomas \& Shellie (2000) report induction of thermotolerance in the third-instar Mexican fruit fly, Anastrepha ludens, after exposure to $44{ }^{\circ} \mathrm{C}$ at a slow heating ramp of $120 \mathrm{~min}$. Thermal death responses in codling moth larvae to high temperature treatments only without preconditioning are also reported (Yokoyama et al., 1991; Wang et al., 2002a,b, 2004).

Fruits also respond to high temperatures by synthesizing heat shock proteins (Sabehat et al., 1996; Woolf et al., 2004), which may help to prevent heat damage in these thermal treatments. If it takes longer for the HSP to disappear after preconditioning in fruits than in insects, then thermal treatments may be effective. However, to date, there are no reported data on the effect of preconditioning on heat shock protein production and larval mortality of codling moth.

The role of HSPs is to protect the cells against damage from high temperature and to aid in recovery once the stress is removed. Some studies have investigated the relationship between insect thermal resistance and the level of heat shock proteins in the insect tissue after exposure to high temperature stress and other environmental stresses (Dahlgaard et al., 1998; Hoffmann et al., 2003).

Heat shock proteins are classified by family based on molecular size, such as HSP90, HSP70 and HSP27/28 (Schelling \& Jones, 1995). The heat shock protein $70 \mathrm{kDa}$ family (HSP70) for insects is the best characterized with respect to its function and molecular weight (Feder \& Hoffmann, 1999; Neven, 2000). Although the role of HSP70 in thermal tolerance in insects is well documented, most of the research has centred on dipterans (Jang, 1992; Vuister et al., 1994; Feder et al., 1996; Dahlgaard et al., 1998; Thomas \& Shellie, 2000). Some small molecular weight heat shock proteins of the flesh fly $S$. crassipalpis were studied by Yocum et al. (1998) and Tammariello et al. (1999). Heat shock proteins are reported in the light brown apple moth E. postvittana (Lester \& Greenwood, 1997); the Colorado potato beetle, Leptinotarsa decemlineata (Yocum, 2001); and the African migratory locust, Locusta migratoria (Qin et al., 2003). However, the heat shock proteins of many other insects remain unknown.

The coddling moth can be controlled by high temperature treatments. In a previous study, the most resistant developmental stage of these insects to high temperature is the fifth-instar (Yin et al., 2006). In addition, it is observed that giving a $35{ }^{\circ} \mathrm{C}$ conditioning treatment before a lethal heat treatment increases the time of exposure necessary for full mortality (Yin et al., 2006). Therefore, the present study aims (i) to determine the effect of a sublethal conditioning temperature of $35^{\circ} \mathrm{C}$ on accumulation of HSP70 in codling moth fifth-instars, as well as changes in protein band patterns in proteins extracted from the insects, and (ii) to examine the relationship between HSP70 protein accumulation and the mortality of codling moths exposed to a high temperature quarantine treatment.

\section{Materials and methods}

\section{Test insects}

Codling moth larvae were reared on a soya-wheat germ starch artificial diet (Toba \& Howell, 1991) at $27^{\circ} \mathrm{C}, 40$ $50 \%$ relative humidity, under an LD $16: 8 \mathrm{~h}$ photoperiod at USDA-ARS Yakima Agricultural Research Laboratory (YARL) in Wapato, Washington.. Third-instars with the diet were placed into a large cooler chest $\left(100 \times 50 \times 50 \mathrm{~cm}^{3}\right)$ with ice bags and were shipped from YARL to Washington State University (WSU) in Pullman, Washington, by overnight delivery. Larvae were reared in the laboratory at the room conditions until they developed to fifth instars, which took 5-7 days.

\section{Insect conditioning and treatment}

One hundred fifth instars of the codling moth were exposed to a temperature of $35^{\circ} \mathrm{C}$ for $0 \mathrm{~min}$ (control), $40 \mathrm{~min}, 2,6$ and $18 \mathrm{~h}$. For the 40-min and 2-h conditioning period, larvae were placed in a heating block system consisting of a closed chamber with two opposing $254 \times 254 \times 18 \mathrm{~mm}$ aluminium blocks with heating pads on each to maintain a controlled temperature set at $35{ }^{\circ} \mathrm{C}$. Temperature was measured with thermocouples; a detailed description of the system is provided by Wang et al. (2002a). The insects were held within a 3-mm space between the two blocks. For 6- and 18-h conditioning, fifth instars in plastic containers $\left(15 \times 10 \times 5 \mathrm{~cm}^{3}\right)$ were placed in an incubator (MDL 3EG, Jouan Inc., Winchester, Virginia) set at $35^{\circ} \mathrm{C}$. Control insects were held at $22{ }^{\circ} \mathrm{C}$ for $18 \mathrm{~h}$. Strips of cotton saturated with distilled water were placed in the containers to maintain humitiy. The containers were covered with fine nylon mesh screens to allow passage of air. Because earlier studies demonstrated that conditioning at $35^{\circ} \mathrm{C}$ for $6 \mathrm{~h}$ resulted in the most heat resistant condition for fifth-instar codling moth (Yin et al., 2006), these conditions were used for the recovery tests. Conditioned larvae were brought to room temperature $\left(22^{\circ} \mathrm{C}\right)$ and allowed to recover for $0.5,1$ or $2 \mathrm{~h}$. They were then given a heat treatment of $5 \mathrm{~min}$ at $50{ }^{\circ} \mathrm{C}$, which causes $100 \%$ mortality in nonconditioned insects (Yin et al., 2006). Larval mortality was calculated as the percentage of dead larvae relative to total treated larvae $\left(N_{0}\right)$ for each treatment $\left(N_{0}-N=100 / N_{0}\right)$, where $N$ is the number of surviving larvae. Treatment mortality was corrected based on the control mortality using the formula of Abbott (1925). Significant differences $(P=0.05)$ among mean values were identified using least significant difference $t$-test (SAS Institute, 1999). Mean values and standard deviations for each temperature-time combination were obtained from three replicates. The insect larvae after different times of conditioning, after recovery, or after heat treatment were placed in sealed $10-\mathrm{mL}$ test glass vials, frozen and stored in a blast freezer at $-70{ }^{\circ} \mathrm{C}$. The conditioning, 
recovery, and thermal heat treatment were replicated three times, each time with 100 insects.

\section{Protein extraction and gel electrophoresis}

Prior to protein extraction, frozen larval samples were rinsed in deionized water. The larvae were then ground in a small tissue grinder after adding a buffer 1: $5(\mathrm{w} / \mathrm{v})$ of 0.5 м Tris- $\mathrm{HCl}, 0.5 \mathrm{~m}$ Sucrose, $50 \mathrm{~mm}$ EDTA, 2\% $\beta$ mercaptoethanol $0.3 \mathrm{M} \mathrm{MgCl}_{2}$ buffer, pH 7.5 (Lester \& Greenwood, 1997; Salvucci et al., 2000; Thomas \& Shellie, 2000). The homogenate was centrifuged at $14000 \mathrm{~g}$ for $10 \mathrm{~min}$ at $4{ }^{\circ} \mathrm{C}$. The protein in the supernatant was extracted with an equal volume of Tris-buffered phenol, and the phenol phase collected and precipitated by the addition of five volumes of $0.1 \mathrm{M}$ ammonium acetate in methanol (Sabehat et al., 1996). The precipitate after centrifugation at $4000 \mathrm{~g}$ for $10 \mathrm{~min}$ was washed three times with $10 \mathrm{~mL}$ of $80 \%$ acetone. The pellet was dried and solubilized in the sample buffer for sodium dodecyl sulphate-polyacrylamide gel electrophoresis (SDS-PAGE). Sample protein concentrations were measured against the concentration of standard proteins (bovine serum albumin) using the Bio-Rad protein assay (Bio-Rad Laboratories, Munich, Germany). Protein samples and standards were diluted at least $1: 2$ with sample buffer and were boiled for $5 \mathrm{~min}$. The samples were run on a precast $10 \%$ SDSPAGE (Laemmli, 1970) using a Bio-Rad Mini-PROTEAN 3 Cell/Power Pac 300 System. For each treatment, loading comprised $10 \mu \mathrm{L}$ of protein in each well (for Coomassie blue staining), or $20 \mu \mathrm{g}$ of protein in each well (for western blotting). The proteins were separating by running at $150 \mathrm{~V}$ at $21.5^{\circ} \mathrm{C}$ for $60 \mathrm{~min}$. After electrophoresis, the proteins were stained with Coomassie Brilliant Blue and fixed with acetic acid. The bands were determined by comparison with molecular weight of the standards. The SDS-PAGE gels were replicated six times.

\section{Protein blotting}

Twenty micrograms of each protein sample were loaded into the wells of gel for western blotting (Life Science Research Products, Electrophoresis and Blotting, BioRad). After running, the gel was assembled into a gel sandwich, which was transferred (running conditions: in $20 \mathrm{~mm}$ Tris base, $150 \mathrm{~mm}$ glycine, at $350 \mathrm{~mA}$ for $45 \mathrm{~min}$ ) to a PVDF membrane using a gel blotter (Bio-Rad). The PVDF membrane was blocked with $5 \%$ nonfat milk and incubated for $1 \mathrm{~h}$ at room temperature. The primary antibody against HSP70 (Antibody HSP70 from mouse; Sigma, St Louis, Missouri) was used at 1: 10000 dilution and incubated overnight at $4{ }^{\circ} \mathrm{C}$. After washing, the membrane was exposed to the secondary antibody (IGG from Goat; Sigma) at 1: 30000 dilution and incubated for $1 \mathrm{~h}$ at room temperature. The bands were visualized with BCIP/NBT tablets solution (Sigma). Western blotting was replicated three times. The intensity of the bands of the western blots was quantified by scanning and use of the PCBas program.

\section{Results}

\section{Protein analysis of fifth-instar codling moth}

Figure 1 shows that a number of new protein bands appeared in extracts of insects held for increasing times at $35^{\circ} \mathrm{C}$, and these bands disappeared rapidly when, after $6 \mathrm{~h}$ at $35^{\circ} \mathrm{C}$, the insects are transferred to $22{ }^{\circ} \mathrm{C}$. With the lengthening of the $35^{\circ} \mathrm{C}$ conditioning times from $40 \mathrm{~min}$ to $18 \mathrm{~h}$ (Fig. 1, lanes $\mathrm{G}$ to $\mathrm{D}$ ), the new bands, found in regions $20,30,70$ and $100 \mathrm{kDa}$, were of increasing intensity. The area of the gel at $70 \mathrm{kDa}$ stained under no stress conditions (Fig. 1, lane $\mathrm{H}$ ), but increased greatly in density of staining during the time of conditioning (Fig. 1, lanes D to $\mathrm{G}$ ), and appeared to decrease as the recovery period was extended (Fig. 1, lanes A to C). The band patterns were different between conditioned and control insects, and the new bands in $40 \mathrm{~min}$ of conditioning (Fig. 1, lane G) were relatively faint compared with those seen after longer conditioning times. These heat-inducible proteins were synthesized increasingly with extension of the conditioning time.

Figure 1 (lanes A, B and C) shows the disappearance of bands that appeared during the conditioning at $35^{\circ} \mathrm{C}$. Between 0.5 and $2 \mathrm{~h}$ of recovery, there was a disappearance of the heat-induced protein bands at high and low molecular weights with a gradual decrease in the heavy staining in the $70-\mathrm{kDa}$ area that appeared after the $35^{\circ} \mathrm{C}$ treatment. The pattern of bands after $2 \mathrm{~h}$ of recovery (Fig. 1C) was similar to the major bands in the control (Fig. 1H).

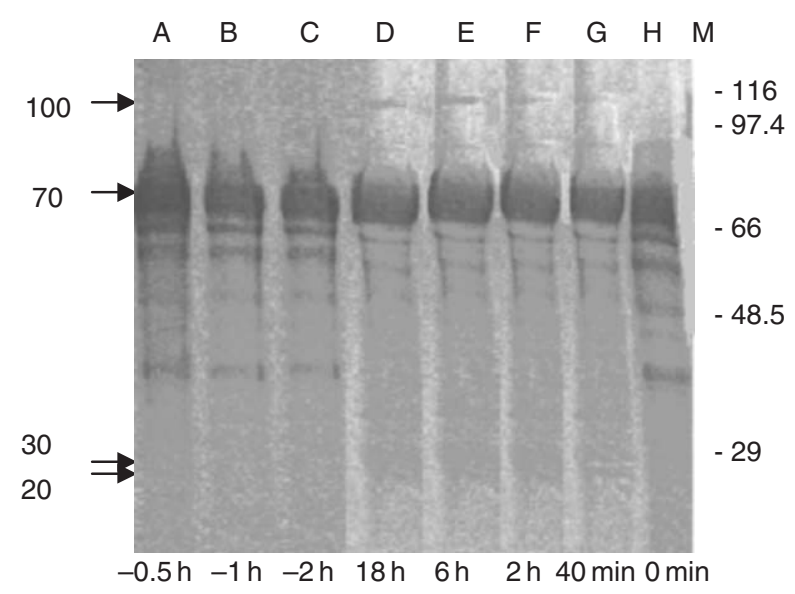

Fig. 1. SDS-PAGE gel $(10 \%)$ of fifth-instar codling moth larvae proteins, showing protein bands in insects conditioned at $35^{\circ} \mathrm{C}$ for periods of $40 \mathrm{~min}$ up to $18 \mathrm{~h}$ (lanes $\mathrm{D}$ to $\mathrm{H}$ ), or conditioned at $35^{\circ} \mathrm{C}$ for $6 \mathrm{~h}$ and recovered at $22{ }^{\circ} \mathrm{C}$ for $0.5 \mathrm{~h}$ up to $2 \mathrm{~h}$ (lanes A to C). Control insects were held $18 \mathrm{~h}$ at $22{ }^{\circ} \mathrm{C}(0 \mathrm{~min}$, lane $\mathrm{H})$. Molecular weight standards are indicated to the right of gel. The arrows on the left-hand side indicate where major new bands appeared during the $35^{\circ} \mathrm{C}$ pretreatment. 
Although there was induction of a number of new protein bands during $35^{\circ} \mathrm{C}$ conditioning, the identification and accumulation of only one protein, HSP70, was followed in more detail.

\section{HSP immunodetection}

HSP70 protein was present after the larvae were conditioned at $35{ }^{\circ} \mathrm{C}$ for different lengths of time (Fig. 2). The HSP70 antibodies reacted more strongly with samples conditioned for $\geq 2 \mathrm{~h}$ than with those for $40 \mathrm{~min}$ of conditioning or samples from control insects $(0 \mathrm{~min})$. Although proteins of that molecular weight were in the Coomassie Blue gel for all the treatments (Fig. 1), it is clear that this HSP70 antibody reacted with heat-inducible HSP and not constitutive HSP, because the control lane ( $0 \mathrm{~min})$ shows no stronger interaction with the antiserum (Fig. 2). High levels of HSP70 were found after $0.5 \mathrm{~h}$ recovery at $22{ }^{\circ} \mathrm{C}$ from $6 \mathrm{~h}$ of conditioning at $35^{\circ} \mathrm{C}$, but was much less after 1 and $2 \mathrm{~h}$ at $22^{\circ} \mathrm{C}$.

\section{Correlation between HSP immunodetection and thermal mortality}

Mortality after treatment at $50{ }^{\circ} \mathrm{C}$ for 5 min was not affected after $40 \mathrm{~min}$ of conditioning, when only a small amount of HSP70 had been synthesized, but survival increased after $\geq 2 \mathrm{~h}$ of conditioning when the amount of HSP70 synthesized was greater (Fig. 3). Conversely, when, after $6 \mathrm{~h}$ at $35^{\circ} \mathrm{C}$, the insects were allowed to recover at $22{ }^{\circ} \mathrm{C}$ before being exposed to $50{ }^{\circ} \mathrm{C}$ for $5 \mathrm{~min}$, the mortality of the insects increased as the recovery time lengthened, which corresponded to the decline, although not disappearance, of the heat-inducible HSP70 (Fig. 4).

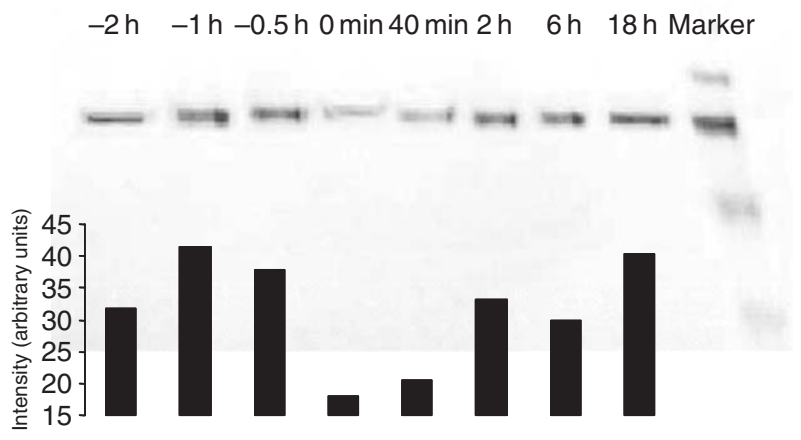

Fig. 2. Western blot of the protein using an antibody to HSP70. The control insects were held at $22{ }^{\circ} \mathrm{C}$ for $18 \mathrm{~h}(0$ min conditioning band). Conditioned insects were held at $35^{\circ} \mathrm{C}$ for $40 \mathrm{~min}, 2,6$ and $18 \mathrm{~h}$. Insects were also conditioned at $35^{\circ} \mathrm{C}$ for $6 \mathrm{~h}$ and then held for recovery at $22^{\circ} \mathrm{C}$ for up $30 \mathrm{~min}, 1$ and $2 \mathrm{~h}(-0.5,-1$ and $-2 \mathrm{~h}$ bands). Molecular weight standards are shown on the right. The densitometric intensity of the bands is shown at the bottom of the figure.
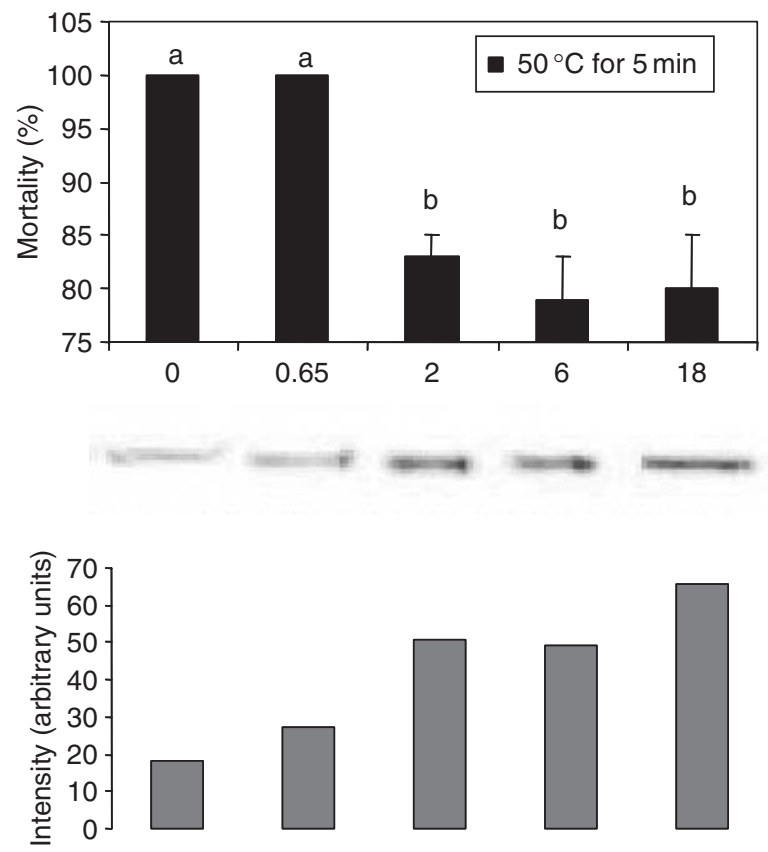

Fig. 3. Western blot for HSP70 protein in fifth-instar codling moth larvae exposed to $35{ }^{\circ} \mathrm{C}$ conditioning for five different periods compared with thermal mortality obtained by $50{ }^{\circ} \mathrm{C}$ for $5 \mathrm{~min}$ after the same conditioning. The upper part of the figure shows the mortality of the insects with different letters indicating statistical difference at $P=0.05$. The middle part of the figure shows the western bands of HSP70 after conditioning and the bottom part of the figure shows the densitometric intensity of the bands. For each time measurement, 100 insects were used.

\section{Discussion}

Conditioning fifth-instar codling moths at $35^{\circ} \mathrm{C}$ increases survival after $5 \mathrm{~min} 50^{\circ} \mathrm{C}$ compared with nonconditioned insects. Wang et al. (2004) show a similar relationship with the fifth-instars of navel orange worm, Amyelois transitella, where conditioned insects survive for longer at high temperature than nonconditioned insects. Similarly, in the light brown apple moth and Queensland fruit fly, conditioning at $38^{\circ} \mathrm{C}$ increases tolerance to subsequent heat disinfestation treatments, reducing disinfestation efficacy (Lester \& Greenwood, 1997; Waddell et al., 2000).

One of the most studied responses to heat stress is the induction of heat shock proteins. Drosophila melanogaster is the insect model most often used for examining the induction of HSPs (Hoffmann et al., 2003). Of the different HSPs, HSP70 is the most abundant family in Drosophila with 10 members, some of which are inducible and others constituative (Roberts et al., 2000). A transgenic increase in copy number of the gene encoding the major inducible HSP70 decreases mortality and developmental defects caused by high temperature stress (Roberts et al., 2000). On the other hand, overexpressing HSPs may also have negative consequences. Flies over-expressing HSP70 have a reduced activity of alcohol dehydrogenase, which is heat 


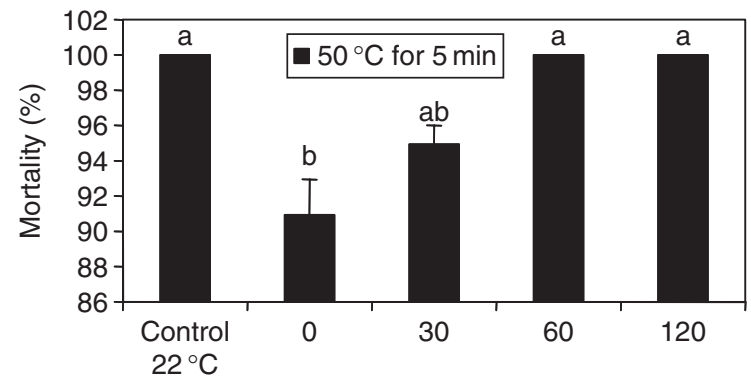

Recovery from $35^{\circ} \mathrm{C}$ conditioning (min)
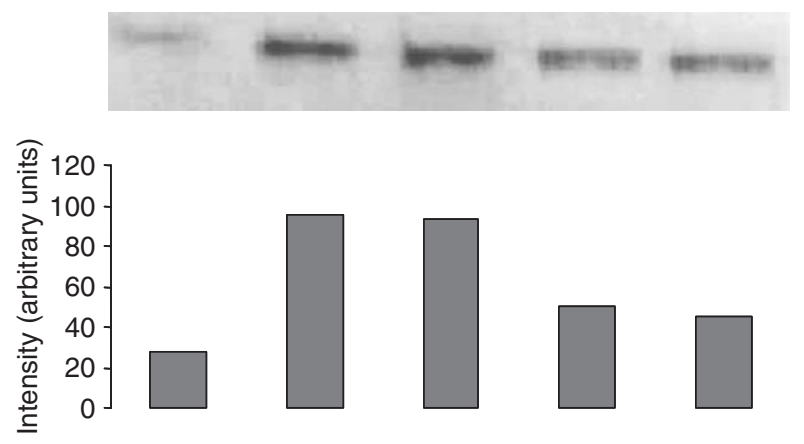

Fig. 4. Western blot for HSP70 in fifth-instar codling moth larvae recovered at $22{ }^{\circ} \mathrm{C}$ for periods of $30 \mathrm{~min}$ up to $120 \mathrm{~min}$ after conditioning at $35^{\circ} \mathrm{C}$ for $6 \mathrm{~h}$ compared with thermal mortality obtained by $50{ }^{\circ} \mathrm{C}$ for $5 \mathrm{~min}$ after the same conditioning. The upper part of the figure shows the mortality of the insects with different letters indicating statistical difference at $P=0.05$. The middle part of the figure shows the western bands of HSP70 and the bottom part of the figure shows the densitometric intensity of the bands. For each time measurement, 100 insects were used.

sensitive, and lactate dehydrogenase, which is not (Krebs \& Holbrook, 2001). It is assumed that when HSP70 is overabundant within the cell, its chaperone activity causes it to bind to nascent peptides leading to inactivation. Therefore, it is important that an elevated level of HSPs is not maintained after the alleviation of a stress situation.

When subjected to a mild heat stress, such as $35^{\circ} \mathrm{C}$, organisms can undergo acclimation to the high temperature. Acclimating insects to a higher temperature than they experience normally causes them to produce less HSPs at an inductive temperature than nonacclimated insects (Sorensen et al., 2001). This response may explain the decrease in HSP70 protein level that is found when the codling moth larvae are held for $18 \mathrm{~h}$ at $35^{\circ} \mathrm{C}$ compared with the level after $6 \mathrm{~h}$.

In fifth-instar codling moth, HSP70 is synthesized quickly during $35{ }^{\circ} \mathrm{C}$ incubation, and does not disappear completely when the insects are returned to $22^{\circ} \mathrm{C}$. However, the thermotolerance induced by the $35^{\circ} \mathrm{C}$ conditioning disappears, and the insects are as sensitive to a $50{ }^{\circ} \mathrm{C}$ treatment as control insects. There may be a threshold level of HSP70 that is reached during this recovery period below which it is no longer protective, and there may be contributions from other heat shock proteins that were not monitored here, and which disappear during the recovery period. It is also possible that additional thermoprotection mechanisms are induced by the $35^{\circ} \mathrm{C}$ conditioning.

Insects, as well as other organisms, accumulate compounds such as sorbitol and trehalose during the acquisition of thermotolerance (Salvucci et al., 2000; Jagdale \& Grewal, 2003). These compounds may be metabolized during the 2-h recovery period and contribute to the dissipation of the thermotolerance induced by conditioning.

What is clear is that conditioning of fifth-instar codling moths at $35^{\circ} \mathrm{C}$ induces thermotolerance in the insects and, from a practical viewpoint, would necessitate longer times at a lethal temperature to guarantee quarantine efficacy.

However, the rapid dissipation of thermotolerance (within $2 \mathrm{~h}$ ) in the insect has other practical implications. Plant tissues such as fruits also develop thermotolerance, and a period at $35-38{ }^{\circ} \mathrm{C}$ can prevent heat damage when the tissues are raised to the high temperature needed for quarantine treatment (Lurie, 1998). The induced thermotolerance in the fruit takes much longer than $2 \mathrm{~h}$ to disappear. Heat-treated tomatoes at $38{ }^{\circ} \mathrm{C}$ retain their thermotolerance for 2 days or longer, and avocados heated for $1 \mathrm{~h}$ at $38{ }^{\circ} \mathrm{C}$ retain thermotolerance to a $50{ }^{\circ} \mathrm{C}$ quarantine treatment for up to 5 days (Sabehat et al., 1996; Woolf et al., 2004). This could mean that, if the insect loses thermotolerance more quickly than the fruit, then a significant delay after a preconditioning before quarantine application may be an optimum quarantine scenario because the induced tolerance in the fruit is maintained whereas it is lost in the insect.

\section{Acknowledgements}

This research was supported by grants from USDA-IFAFS (00-52103-9656) program, and from Washington State University IMPACT Center. We thank Millie Heidt and Michele Watkins (USDA-ARS, Wapato, Washington), Xianming Chen, Margo M. Haines, Lee A. Hadwiger and Yujia $\mathrm{Wu}$ (Washington State University, Pullman, Washington) for technical assistance. We also thank G.D. Yocum and E.B. Jang for reviewing the manuscript and their constructive suggestions.

\section{References}

Barnes, M.M. (1991) Codling moth occurrence, host race formation, and damage. Tortricide Pests: Their Biology, Natural Enemies and Control (ed. by L. P. S. van der Geest and H. H. Evenhuis), pp. 313-327. Elsevier, New York, New York.

Beckett, S.J. \& Evans, D.E. (1997) The effects of thermal acclimation on immature mortality in the Queensland fruit fly Bactrocera tryoni and the light brown apple moth Epiphyas postivtana at a lethal temperature. Entomologia Experimentalis et Applicata, 82, 45-51. 
Dahlgaard, J., Loeschcke, V., Michalak, P. \& Justesen, J. (1998) Induced thermotolerance and associated expression of the heatshock protein $\mathrm{Hsp} 70$ in adult Drosophila melanogaster. Functional Ecology, 12, 786-793.

Feder, M.E., Cartaño, N.V., Milos, et al. (1996) Effect of engineering Hsp70 copy number on Hsp70 expression and tolerance of ecologically relevant heat shock in larvae and pupae of Drosophila melanogaster. Journal of Experimental Biology, 199, 1837-1844.

Feder, M.E. \& Hoffmann, A.A. (1999) Heat shock proteins, molecular chaperones, and the stress response: evolutionary and ecological physiology. Annual Review of Physiology, 61, 243-282.

Hallman, G.J. (1994) Mortality of third-instar Caribbean fruit fly (Diptera: Tephritidae) rared at three temperatures and exposed to hot water immersion or cold storage. Journal of Economic Entomology, 87, 405-408.

Hallman, G.J. \& Mangan, R.L. (1997) Concerns with temperature quarantine treatment research. Proceedings of the Annual International Research Conference on Methyl Bromide Alternatives and Emission Reduction, 79-1-79-4.

Hansen, J.D., Drake, S.R. \& Heidt, M.L. (2002) Codling moth survival in cherry: effect of cultivars and fruit maturity. Journal of American Pomology Society, 56, 156-163.

Hoffmann, A.A., Sorensen, J.G. \& Loeschcke, V. (2003) Adaptation of Drosophila to temperature extremes: bringing together quantitative and molecular approaches. Journal of Thermal Biology, 28, 175-216.

Jagdale, G.B. \& Grewal, P.S. (2003) Acclmation of entomopathogenic nematodes to novel temperatures: trehalose accumulation and the acquisition of thermotolerance. International Journal for Parasitology, 33, 145-152.

Jang, E.B. (1992) Heat shock proteins and thermotolerance in a cultured cell line from the Mediterranean fruit fly, Ceratitis capitata. Archives of Insect Biochemistry and Physiology, 19, 93-103.

Krebs, R. \& Holbrook, S. (2001) Reduced enzyme activity following Hsp70 overexpression in Drosophila melanogaster. Biochemical Genetics, 39, 73-82.

Laemmli, U.K. (1970) Cleavage of structural proteins during the assembly of the head of bacteriophage $\mathrm{T}_{4}$. Nature, 227, 680 .

Lester, P.J. \& Greenwood, D.R. (1997) Pretreatment induced thermotolerance in lightbrown apple moth (Lepidoptera: Tortricidae) and associated induction of heat shock protein synthesis. Journal of Economic Entomology, 90, 199-204.

Lurie, S. (1998) Postharvest heat treatments of horticultural crops: commodity responses. Postharvest Biology and Technology, 14, 257-269.

Ministry of Agriculture and Forestry - Republic of Korea (1982) Plant protection law enforcement regulation. Ministerial Order no. 848, Article 3, Annexed Table.

Ministry of Agriculture, Forestry and Fisheries - Japan (1950) Plant protection law enforcement regulations. Ministerial Order no. 73, Annexed Table 1.

Neven, L.G. (2000) Physiological responses of insects to heat. Postharvest Biology and Technology, 21, 103-111.

Qin, W., Tyshenko, M.G., Wu, B.S. et al. (2003) Cloning and characterization of a member of the $h s p 70$ gene family from Locusta migratoria, a highly thermotolerant insect. Cell Stress and Chaperones, 8, 144-152.

Roberts, S.P., Feder, M.E. \& Posluszny, J.A. (2000) Developmental and fitness consequences of natural thermal stress and Hsp70 copy number in Drosophila melanogaster. American Zoologist, 40, 1189-1190.

Sabehat, A., Weiss, D. \& Lurie, S. (1996) The correlation between heat-shock protein accumulation and persistence and chilling tolerance in tomato fruit. Plant Physiology, 110, 531-537.

Salvucci, M.E., Stecher, D. \& Henneberry, T. (2000) Heat shock proteins in whiteflies, an insect that accumulates sorbitol in response to heat stress. Journal of Thermal Biology, 25, 363-371.

Schelling, D. \& Jones, G. (1995) Analysis of induction of hsc70, Hsp82 and juvenile hormone esterase genes by heat shock in Trichoplusia ni. Journal of Insect Physiology, 42, 295-301.

Sorensen, J.G., Dahlgaard, J. \& Loeschcke, V. (2001) Genetic variation in thermal toleranceamong natural populations of Drosophila buzzattii: down regulation of Hsp70 expression and variation in heat stress resistance traits. Functional Ecology, 15, 289-296.

Tammariello, S.P., Rinehart, J.P. \& Denlinger, D.L. (1999) Desiccation elicits heat shock protein transcription in the flesh fly, Sarcophaga crassipalpis, but does not enhance tolerance to high or low temperatures. Journal of Insect Physiology, 45, 933-938.

Thomas, D.B. \& Shellie, K.C. (2000) Heating rate and induced thermotolerance in Mexican fruit fly larvae, a quarantine pest of citrus and mangoes. Journal of Economic Entomology, 93, 1373-1379.

Toba, H.H. \& Howell, J.F. (1991) An improved system for massrearing codling moths. Journal of the Entomological Society of British Columbia, 88, 22-27.

Vuister, G.W., Kim, S., Orosz, A. et al. (1994) Solution structure of the DNA-binding domain of Drosophila heat shock transcription factor. Nature Structural Biology, 1, 605-614.

Waddell, B.C., Jones, V.M., Petry, et al. (2000) Thermal conditioning in Bactrocera tryoni eggs following hot-water immersion. Postharvest Biology and Technology, 21, 113-128.

Wang, S., Ikediala, J.N., Tang, J. \& Hansen, J.D. (2002a) Thermal death kinetics and heating rate effects for fifth-instar Cydia pomonella (L.). Journal of Stored Products Research, 38, 441-453.

Wang, S., Tang, J., Johnson, J.A. \& Hansen, J.D. (2002b) Thermal death kinetics of fifth-instar navel orangeworms (Lepidoptera: Pyralidae). Journal of Stored Products Research, 38, 427-440.

Wang, S., Yin, X., Tang, J. \& Hansen, J.D. (2004) Thermal resistance of different life stages of codling moth (Lepidoptera: Tortricidae). Journal of Stored Products Research, 40, 565-574.

Wearing, C.H., Hansen, J.D., Whyte, C. et al. (2001) The potential for spread of codling moth (Lepidoptera: Tortricidae) via commercial sweet cherry fruit: a critical review and risk assessment. Crop Protection, 20, 465-488.

Woolf, A., Bowen, J., Ball, S. et al. (2004) A delay between a $38^{\circ} \mathrm{C}$ pretreatment and damaging high and low temperature treatments influences pretreatment efficacy in 'Hass' avocados. Postharvest Biology and Technology, 34, 143-153.

Yin, X., Wang, S., Tang, J. \& Hansen, J. (2006) Thermal resistance of fifth-instar Cydia pomonella (Lepidoptera: Tortricidae) as affected by pretreatment conditioning. Journal of Stored Products Research, 42, 75-85.

Yocum, G.D. (2001) Differential expression of two HSP 70 transcripts in response to cold shock, thermoperiod, and adult diapause in the Colorado potato beetle. Journal of Insect Physiology, 47, 1139-1145.

Yocum, G.D. \& Denlinger, D.L. (1992) Prolonged thermotolerance in the fresh fly, Sarcophaga crassipalpis, does not require continuous expression or persistence of the $72 \mathrm{kDa}$ heat shock protein. Journal of Insect Physiology, 38, 603-609. 
Yocum, G.D., Joplin, K.H. \& Denlinger, D.L. (1998) Upregulation of a $23 \mathrm{kDa}$ small heat shock protein transcript during pupal diapause in the flesh fly, Sarcophaga crassipalpis. Insect Biochemistry and Molecular Biology, 28, 677-682.

Yokoyama, V.Y., Miller, G.T. \& Dowell, R.V. (1991) Response of codling moth (Lepidoptera: Tortricidae) to high temperature, a potential quarantine treatment for exported commodities. Journal of Economic Entomology, 84, 528-531.

Accepted 20 December 2005

First published online 19 June 2006 